\title{
Targeting Effect of Traditional Chinese Medicine
}

\author{
Rui-Zhi Zhao \\ Second Affiliated Clinical College, Guangzhou University of Chinese Medicine, \\ Nei Huan XiLu, Guangzhou Daxue Cheng, Guangzhou, \\ China
}

\section{Introduction}

Most drugs have a widespread distribution in vivo, and effects beyond the disease site need to be avoided. As to herbs, it contains many components with different structure and varied effects, how to achieve the desired effect at the required site is a great challange. In ancient China, people usually get this goal by co-administration of other drugs, and in thousands of years, the experience was summarized as meridian guide theory. Since meridian guide theory is based on meridian distribution and compatibility, therefore, we should give a brief review about meridian, meridian distribution, and meridian guide drug.

In ancient China, diseases were treated by many methods, such as acupuncture, stone needle, drug, medicated bath, application, fumigate, and surgery. Concept of meridian was raised with acupuncture. In <Huangdi's Internal Classics>, the first monograph of China published at about $200 \mathrm{BC}$, diseases were divided according to their meridian, "meridian belongs to entrails inside and artus outside". There are 12 meridians, named as lung meridian, large intestine meridian, pericardium meridian, San Jiao meridian, heart meridian, small intestine meridian, spleen meridian, stomach meridian, liver meridian, gallbladder meridian, kidney meridian and urinary bladder meridian. Name of meridian is based on the main entrails the disease correlate and the route it will pass. And in $<$ Huangdi's Internal Classics $>$, there are descriptions about the position, shape and weight of liver, heart, spleen, lung, kidney, intestine, stomach, gallbladder and urinary bladder, which are similar to that of modern anatomy. However, in ancient times, the anatomy was rough, and some version is different from modern views. For example, kidney is the main organ in kidney meridian, the function of "kidney" in traditional Chinese medicine includes kidney and genitical gland located near kidney. At that time, disease diagnosis and treatment especially in acupuncture was based on their meridian, such as taiyang diseases, yangming diseases, etc.

In Han dynasty, the famous physician Zhang Zhong-Jing described a method of diagnose analyse and differentiate febrile diseases in accordance with the theory of six pairs of channels in his book < Treatise on Febrile Diseases $>(\mathrm{Fu}, 1990)$. Thereafter, drug use was summarized according to syndrome- differentiation of the six meridians. For example, nutgrass galingale rhizome is used to treat liver diseases, therefore, its meridian belongs to liver; fritillariae tuber is used to treat lung diseases such as cough, asthma, therefore, its meridian belongs to Lung; borneol is used to treat heart diseases, its meridian distribution is heart, etc. Some drugs have a wide use, its meridian distribution may be two or three entrails. For example, bupleuriradix is used to treat diseases of liver, Sanjiao, arcula cordis, 
and it belonges to these three meridians. And this is the basis for the formation of meridian distribution theory. In Tang and Song dynasty, there were some descriptions about drug orient and site-direct effect in books <Shi Liao Ben Cao>, <Supplement to the Herbal>, $<$ Amplification on Canon of Materia Medica $>$ and <Su Shen Liang Fang $>$. Thereafter, in Jin and Yuan dynasty, the famous physician Zhang Jie-Gu summarized these results and combined with his own experiment, raised the concept of meridian distribution. In his book $<$ Zhen Zhu Lang>, and <Yi Xue Qi Yuan>, he summarized the experience of drug use according to meridian channels, such as "drug used to remove fire in ZANG FU-organ", "Meridian Guide drug of channels", and described meridian distribution as an important item of drug property. He thought that drug effect is related to its channal, and when used properly, the effect would be great. For example, Coptis chinensis, schtellaria, paeoniae radix, anemarrhenae, caulis hocquartiae, phellodendricortex, and gypsum all had the effect of purging pathogenic fire, however, Coptis chinensis is mainly used to purge the sthenic heart-fire, scutellaria is mainly used to purte the White, paeoniaeradix is mainly used to purge the sthenic liver-fire, caulis hocquartiae is used to rush down the fire in small intestine, phellodendricortex is mainly used to purge the fire in bladder. His disciple, famous physician Li Dong-Yuan and Wang Hao-Gu inherited his theory and developed it. In the book < Yong Yao Fa Xiang> of Li Dong-Yuan and <Materia Medica of Decoction> of Wang Hao-Gu, meridian distribution theory was used and improved. In $<$ Materia Medica of Decoction>, there were 242 different kinds of drugs, among them, 80 were described as drugs with meridian distribution. In this book, drugs with meridian distribution were summarized in a table, named as "Guide profiles of various meridians". Due to its effectiveness in choosing drugs to formulate prescription, as it appeared, it was accepted by many physicians and more and more experience about drug meridian distribution was summarized. Then, in Ming dynasty, two famous physicians Liu Wen-Tai and Jia Ru-Li described meridian distribution as an indispensable content of drug property in their book <Ben Cao Pin Hui Jing Yao> and <Yao Pin Hua Yi> respectively. Li Shi-Zhen, a famous physician and pharmacist in Ming dynasty, inherited and developed the theory of meridian distribution of Zhang Jie-Gu in his world-famous book <Compendium of Materia Medica>, and indicated that "Chinese lovage is TaiYang meridian drug", "gypsum is cold Yangming meridian drug" etc. The meridian distribution of herbs was introduced when discussing drug property, such as "ephedra herb is the herb for lung meridian specially, when treating lung diseases, it is usually used." "frenugreek, herbs of right kidney, when kidney-YANG is deficient, it is used when cold-QI incubate in body and could not return to Yuan", "gastrodiarhizome is Qifen herbs belonging to liver meridian, in <Huangdi's Internal Classics $>$, it was indicated that all kinds of dazzling belongs to liver meridian, therefore, gastrodiarhizome could treat dizzy." Afterwards, meridian distribution was extensively described in books <Ben Cao Jing Shu> of Liao Xi-Yong, <Lei Gong Pao Zhi Yao Xing Jie> and <Ben Cao Tu Jie> by Li Zhong-Zi, , and more and more people accepted meridian distribution theory.

Meridian guide theory is the combination of meridian distribution and compatibility. It is first proposed in Qin and Han dynasty, and was developed in Tang and Song dynasty, formed at Jin and Yuan dynasty, completed in Ming and Qing dynasty. At 200 BC, in the first herb book <Shennong's herbal>, there was description that "Jun Gui is the message of other drugs". In Wei and Jin dynasty, famous physician Tao Hong-Jing described in his book <Ming Yi Bie Lu> that "cinnamomicortex guides other drugs". In Bei Song dynasty, Kou Zong-Shuang described in his book <Amplification on Canon of Materia Medica> that "Zhang Zhong-Jing used Alismae rhizoma in "Ba Wei Wan", just used it to guide 
cinnamomicortex and aconite root into kidney meridian, and no other means". In Jin and Yuan dynasty, Zhang Jie-Gu raised the concept of meridian guide drug. In his book <Zhen Zhu Lang>, he called drugs which could enforce other drugs effect at the meridian of its own as meridian guide drug, and listed meridian guide drug for twelve meridians. His disciple Li Dong-Yuan developed this idea and the theory. And then, in the book $<$ Compendium of Materia Medica>, Li Shi-Zhen summarized the work of previous physicians, combined his and his father's experience in treating diseases, and revised the meridian guide drug of twelve channels. Also in this book, it is said that "ramuluscinnamomi guides other drugs to arm", "achyranthisradix guides other drugs to the lower part of the body" etc. Afterwards, many physicians exercised this method for diseases treatment, and got good results.

The twelve meridian guide drugs are: platycodonradix, angelica root, cimicifugae for lung meridian, gypsum and angelica root for large intestine meridian, cortex moutan and bupleuriradix for pericardium meridian, forsythia suspensa and bupleuriradix for San Jiao meridian, coptis chinensis, asariradix and borneol for heart meridian, Chinese lovage and phellodendri for small intestine meridian, atractylodes and cimicifugae for spleen meridian, angelica root, gypsum and pueraria for stomach meridian, vinger-baked bupleuriradix, evodiaefructus, and green tangerine peel for liver meridian, green tangerine peel and bupleuriradix for bladder meridian, cassia and anemarrhenae for kidney meridian, and incised notopterygium rhizome for urinary bladder meridian. There are some crossovers in meridian guide drug among different channels, for example, bupleuriradix and cimicifugae are meridian guide drugs for four channels, angelica root is the meridian guide drug for three channels. Besides twelve meridian guide drugs, there are some drugs for site targeting, such as chuanxiong for headache; ramulus cinnamomi and mulberry twig for Brachialgia; achyranthisradix for melosalgia; notopterygiirhizoma for cervical part disease etc. Many physicians practised meridian guide method in treating diseases and had a good effect, and they recorded their thoughts in their books. You Zai-Jing, a famous physician, said in his book < Yi Xue Du Shu Ji > that "soldiers could not reach enemies' place if there is not a guide, and drugs could not reach the disease site if there is not a meridian guide drug". Another physician in Qing dynasty, Shen Shi-Pao said that " meridian guide drug could induce other drugs to the disease site, and a great effect could be achieved with less drug used". Many famous prescriptions contained meridian guide drug, such as bupleuriradix in "Xiao Chai Hu Tang", gypsum in "Bai Hu Tang", kudzuvine root in "Ge Gen Qin Lian Tang", platycodiradix in "Sen Ling Bai Zhu San", and evodiaefructus in "Zuo Jin Wan", achyranthisradix in "San Miao San" and "Hu Qian Wan". Even in modern times, many famous physicians indicated that using meridian guide drug is an effective way for drug targeting (R.Z. Zhao et al, 2005).

Nowdays, more and more drugs are found to have side effects, and these effects affected clinical results especially for cancer treatment, about $30 \%$ patients give up treatment due to serious side effects of anticancer drugs. Many technologies are used to increase the therapeutic effect and reduce the side effect. However, site-directed pharmaco-delivery is a desirable but elusive goal. Although there are great achievements in target delivery, the clinical results were beyond people's expectation due to the difference between animals and human beings. The concept of meridian guide drug is similar to that of target delivery system, may be a new way for targeting delivery. Therefore, some studies had been carried out to demonstrate the meridian guide theory by experiment. 


\section{Modern study of meridian guide drug}

At present, two methods are usually used to study meridian guide theory. One is pharmacokinetics method. This method demonstrated the effect of meridian guide drug by comparing drug distribution before and after co-administration with meridian guide drugs. This method is based on the hypothesis that drug effect is dependent on its concentration. The second method is pharmacological method. Meridian guide effect was investigated by comparing the target site effect between drug and their co-administration with meridian guide drugs. This method is based on the clinical definition of meridian guide drug. Vinegar-baked bupleuriradix, meridian guide drug of liver, platycodiradix, meridian guide drug of lung, borneol, meridian guide of heart meridian, and achyranthisradix, meridian guide drug of legs have been studied.

\subsection{Study of liver meridian guide drug: vinegar-baked bupleuriradix}

Bupleuriradix, is the dry radix of Bupleurum Chinense DC, and B. Scozoneri folium wide. It tastes acrid, and belongs to liver, cholecyst, Sanjiao and pericardium meridian. It is usually used in the treatment of influenza, fever, malaria, hepatitis, jaundice, nephritis, dizziness, bitter taste in the mouth, lung disease, cancer, and menstrual disorders in China, Japan, and other Asia. Pharmacological study showed that it had the effect of anti-inflammatory (S.M.Chen et al, 2008), antiviral activities (Chiang, 2003), antioxidant and hepatoprotective effect (B.J. Wang et al, 2004) etc. It is the meridian guide drug of liver, pericardium, gall bladder and Sanjiao meridian. In traditional Chinese medicine theory, it is regarded that drugs with sour taste enters liver first, and when baked with vinegar, it is the liver meridian guide only. It is described in the book <Ben Cao Zheng Yi> that "...besides, there is stagnation in collaterals and subcollaterals of liver, add few of bupleuriradix, the effect is quick".

Li Xiao-Dong and Nie Sa et al studied the effect of vinegar on pharmacological and chemical of bupleuriradix. The results showed that both pharmacological effect and components in the drug changed a little bit due to the vinegar-baked procedure (X.D. Li, 2000; S.Nie et al; 2008). It was demonstrated that vinegar-baked bupleuriradix had a much stronger effect on acesodyne and bile secretion than that of the bupleuriradix (J.Wu, 2008; S.Q Nie et al; 2002). Therefore, vinegar-baked bupleuriradix was extensively used in the liver diseases treatment medicines (Kou et al, 2006), such as DA Chai Hu Tang, Xiao Yao San, Xiao Chai Hu Tang etc. The study method was pharmacokinetics based.

\subsubsection{Vinegar-baked bupleuriradix affected drug distribution}

Four components were chosen in studying the liver targeting effect of vinegar-baked bupleuriradix, these are resveratrol (R.Z. Zhao et al., 2009), rhein (R.Z. Zhao et al., 2010), oxymatrine (unpublished data), and gentiopicroside (unpublished data). Their structure belongs to chrysophenine glycoside, anthraquinone, alkaloid and iridoid glycode respectively. In these studies, except resveratrol, animals were divided into two large groups according to dose of the components, and in each large group, animals were divided into four groups based on the dose of vinegar-baked bupleuriradix. For resveastrol, there was only one large group, and subgroup was similar to that of the other studies.

The detail of the experiment is listed in Table 1. For oral administration, components were suspended in solutions containing $1 \%$ sodium carboxymethylcellulose or in vinegar-baked bupleuriradix solutions containing $1 \%$ sodium carboxymethylcellulose. At predetermined 
time points, six animals were taken out from each group and blood was collected via heart puncture. Tissues of interest (heart, liver, spleen, lung, and kidney) were collected immediately after cervical dislocation and were blotted dry with tissue paper. Plasma and tissue samples were frozen at $-80^{\circ} \mathrm{C}$ until analysis.

\begin{tabular}{|l|l|l|l|l|l|l|}
\hline Component & Animal & $\begin{array}{l}\text { Detection } \\
\text { method }\end{array}$ & $\begin{array}{l}\text { Detected } \\
\text { components }\end{array}$ & subgroups & $\begin{array}{l}\text { Drug } \\
\text { dose } \\
(\mathrm{mg} / \mathrm{kg})\end{array}$ & $\begin{array}{l}\text { Dose of } \\
\text { vinegar-baked } \\
\text { bupleuriradix } \\
(\mathrm{mg} / \mathrm{kg})\end{array}$ \\
\hline resveratrol & mice & HPLC & resveratrol & 4 & 200 & $300,600,1200$ \\
\hline rhein & rats & HPLC & $\begin{array}{l}\text { Rhein and } \\
\text { conjugated } \\
\text { rhein }\end{array}$ & 8 & 80,40 & $300,600,1200$ \\
\hline oxymatrine & mice & HPLC-MS & $\begin{array}{l}\text { Oxymatrine and } \\
\text { matrine }\end{array}$ & 8 & 80,10 & $400,800,1200$ \\
\hline gentiopicroside & mice & HPLC-MS & gentiopicroside & 8 & 100,50 & $400,800,1200$ \\
\hline
\end{tabular}

Table 1. Experiment design of liver targeting effect of vinegar-baked bupleuriradix

In all the studied animal groups, vinegar-baked bupleuriradix showed liver targeting effects for all the components with different degree. This effect is dependent on the dose of vinegarbaked bupleuriradix, components and its structure. Table 2 listed the most effective group within the study.

Vinegar- baked bupleuriradix enhanced other drugs liver distribution by three ways. First, it increased the Cmax of other drugs in liver, this indicated that vinegar-baked bupleuriradix enhanced liver uptake of other drug. This effect is component structure related. Among these four components, rhein is the most sensitive drug to the effect of vinegar-baked bupleuriradix, the maximal increased Cmax ratio in liver was 565\%; second sensitive component is oxymatrine, the maximal increased Cmax ratio in liver was $89 \%$, the third is gentiopicroside, the maximal increased Cmax ratio was 21\%; and resveratrol is the least sensitive to the effect of vinegar baked bupleuriradix, its Cmax had marginal change. AUC is a parameter determined by Cmax and elimination rate. When using AUC as the evaluation criteria, rhein is still the most sensitive component to the effect of vinegar-baked bupleuriradix, second is oxymatrine. However the third is resveratrol, the increased AUC in liver was $79 \%$, and gentiopicroside was the most insensitive component to the effect of vinegar-baked bupleuriradix. It should be indicated that although vinegar-baked bupleuriradix had marginal effect on the uptake of resveratrol, it decreased the elimination rate of resveratrol in liver significantly, also induced an increase in AUC.

Second, vinegar-baked bupleuriradix decreased AUC and Cmax of these components in other tissues. Rhein is the most sensitive components to the effect of vinegar-baked bupleuriradix. Low dose of vinegar-baked bupleuriradix decreased the distribution of rhein in other tissues except liver, and the decreased AUC ratio was $82 \%, 57 \%, 30 \%, 25 \%$ and $15 \%$ for spleen, heart, blood, lung and kidney respectively. The second sensitive component was resveratrol, high dose of vinegar-baked bupleuriradix decreased the distribution of resveratrol in kidney, spleen, heart and lung significantly, the decreased AUC ratio was $30 \%, 30 \%, 32 \%$ and $30 \%$ respectively. The third sensitive component was oxymatrine, medium dose of vinegar-baked bupleuriradix decreased the distribution of oxymatrine in blood, spleen, heart, and lung, the decreased AUC ratio was 33\%, 27\%, 17\% and 19\%, the 
least sensitive components was gentiopicroside, medium dose of vinegar-baked bupleuriradix only decreased the AUC of gentiopicroside in blood and lung, the decreased ratio was $17 \%$ and $18 \%$ respectively.

\begin{tabular}{|c|c|c|c|c|c|}
\hline Drugs & $\begin{array}{l}\text { AUC } \\
\text { Changed } \\
\text { extent in } \\
\text { liver }\end{array}$ & $\begin{array}{l}\text { Cmax } \\
\text { Changed } \\
\text { extent in } \\
\text { liver }\end{array}$ & $\begin{array}{l}\text { AUC Changed extent in } \\
\text { other tissues }\end{array}$ & $\begin{array}{l}\text { Cmax Changed } \\
\text { extent in other } \\
\text { tissues }\end{array}$ & $\begin{array}{l}\text { Drug } \\
\text { distribution } \\
\text { original }\end{array}$ \\
\hline resveratrol & $79 \%$ & $\begin{array}{l}\text { No } \\
\text { significance }\end{array}$ & $\begin{array}{l}-44 \% \text { in lung, } 58 \% \text { in } \\
\text { heart, and } 42 \% \text { in kidney }\end{array}$ & \begin{tabular}{|l|}
$-46 \%$ in kidney, - \\
$23 \%$ in lung, and - \\
$16 \%$ in heart
\end{tabular} & $\begin{array}{l}\text { Kidney }>\text { liver }> \\
\text { lung }>\text { blood }> \\
\text { heart> spleen }\end{array}$ \\
\hline rhein & $264 \%$ & $226 \%$ & $\begin{array}{l}-72 \%,-57 \%,-30 \%,-25 \%,- \\
15 \% \text { in spleen, heart, } \\
\text { blood, lung and kidney } \\
\text { respectively }\end{array}$ & \begin{tabular}{|l|}
$-31 \%$ in heart, and \\
$-65 \%$ in spleen
\end{tabular} & $\begin{array}{l}\text { Kidney }>\text { lung }> \\
\text { blood }>\text { liver }> \\
\text { spleen }>\text { heart }\end{array}$ \\
\hline $\begin{array}{l}\text { Conjugated } \\
\text { rhein }\end{array}$ & $21 \%$ & \begin{tabular}{|l|} 
No \\
significance
\end{tabular} & $\begin{array}{l}-53 \%,-48 \%,-43 \%,-39 \% \\
\text { and }-30 \% \text { in lung, heart, } \\
\text { spleen, kidney, and } \\
\text { blood respectively }\end{array}$ & \begin{tabular}{|l|}
$-36 \%$ in heart, and \\
$-23 \%$ in kidney
\end{tabular} & $\begin{array}{l}\text { Spleen }>\text { lung }> \\
\text { kidney> heart }> \\
\text { liver } \approx \text { blood }\end{array}$ \\
\hline oxymatrine & $152 \%$ & $89 \%$ & $\begin{array}{l}-33 \%,-17 \%,-27 \%,-19 \% \\
\text { in blood, heart, spleen } \\
\text { and lung respectively }\end{array}$ & \begin{tabular}{|l|}
$56 \%$ in kidney, - \\
$36 \%$ in lung, $-15 \%$ \\
in blood
\end{tabular} & $\begin{array}{l}\text { Blood }>\text { lung }> \\
\text { spleen }>\text { kidney }> \\
\text { liver } \approx \text { blood }\end{array}$ \\
\hline matrine & $32 \%$ & $20 \%$ & \begin{tabular}{|l|}
$-73 \%,-37 \%,-35 \%,-16 \%$ \\
in lung, blood, heart, and \\
kidney respectively
\end{tabular} & \begin{tabular}{|l|}
$-63 \%,-46 \%,-41 \%$, \\
$35 \%,-28 \%$ in heart, \\
kidney, blood, \\
spleen, and lung \\
respectively
\end{tabular} & $\begin{array}{l}\text { Blood }>\text { liver }> \\
\text { kidney }>\text { spleen } \approx \\
\text { heart } \approx \text { lung }\end{array}$ \\
\hline $\begin{array}{l}\text { Gentio- } \\
\text { picroside }\end{array}$ & $\begin{array}{l}\text { No } \\
\text { significance }\end{array}$ & $20 \%$ & $\begin{array}{l}-39 \%,-27 \%,-27 \%,-18 \% \\
\text { in kidney, heart, spleen, } \\
\text { lung respectively }\end{array}$ & $\begin{array}{l}-35 \%,-36 \%-15 \% \text { in } \\
\text { heart, spleen and } \\
\text { kidney } \\
\text { respectively }\end{array}$ & $\begin{array}{l}\text { Kidney }>\text { blood }> \\
\text { liver }>\text { lung }> \\
\text { heart }>\text { spleen }\end{array}$ \\
\hline
\end{tabular}

Table 2. The results of vinegar-baked bupleuriradix on the AUC, Cmax of other components, listed results were the most effective groups when using relative targeting ratio as evaluation index.

Third, vinegar-baked bupleuriradix decreased the elimination rate of all these four components in liver, but increased their elimination rate in other tissues. This may be another reason for AUC increase in liver and AUC decrease in other tissues.

The liver targeting effect of vinegar-baked bupleuriradix also depended on drug and vinegar-baked bupleuriradix dose. For resveratrol and gentiopicroside, medium dose of vinegar-baked bupleuriradix had the strongest effect. For rhein, in high rhein dose group, low dose of vinegar-baked bupleuriradix had the strongest effect, but in low rhein dose group, high dose of vinegar-baked bupleuriradix had the strongest effect. For oxymatrine, in high oxymatrine dose group, high and medium dose of vinegar-baked bupleuriradix had the strongest effect. For gentiopicroside, rhein and oxymatrine, all components were sensitive to the effect of vinegar-baked bupleuriradix at their high dose than that at low dose. 
In the study of rhein and oxymatrine, effects of vinegar-baked bupleuriradix on the distribution of their metabolites were also studied. Interestingly, similar phenomenon was observed when the index is conjugated rhein and matrine. Vinegar-baked bupleuriradix increased not only their distribution in liver, but also decreased their distribution in other tissues, also showing a liver targeting effect. Compared the sensitivity of rhein, oxymatrine together with their metabolites to the effect of vinegar-baked bupleuriradix, rhein metabolite was less sensitive than its native form, and rhein dose had marginal effect. However, the sensitivity of oxymatrine to the effect of vinegar-baked bupleuriradix was dependent on its dose, in high dose group of oxymatrine, oxymatrine was more sensitive than its metabolite, anyhow, in low dose group of oxymatrine, matrine was more sensitive than its native form.

When comparing their own distribution and the effect of vinegar-baked bupleuriradix, it is found that for the components which are sensitive to the effect of vinegar-baked bupleuriradix, their main distribution is not in liver. For rhein and oxymatrine, liver distribution was only $5 \%$ and $3.8 \%$ of the total drug in vivo respectively. However, the two components were less sensitive to the effect of vinegar-baked bupleuriradix, their distribution in liver was relatively high, AUC in liver was $17 \%$ and $17.9 \%$ for gentiopicroside and resveratrol respectively.

\subsubsection{Liver targeting effect mechanism of Vinegar-baked bupleuriradix}

Effect of vinegar-baked bupleuriradix on drug distribution implied that vinegar-baked bupleuriradix may affect cell uptake of the drug and this is related with membrane constituents. Therefore, the effect of vinegar-baked bupleuriradix on membrane permeability, membrane constituents, pHi and morphology of BRL cell line were investigated (unpublished data). In these studies, samples were divided into four groups according to the concentration of vinegar-baked bupleuriradix, $10 \mathrm{mg} / \mathrm{mL}, 2 \mathrm{mg} / \mathrm{mL}, 0.4$ $\mathrm{mg} / \mathrm{mL}$ and drug free group, respectively. In each group, samples were further divided into $3 \mathrm{~h}, 6 \mathrm{~h}, 10 \mathrm{~h}, 18 \mathrm{~h}, 24 \mathrm{~h}, 48 \mathrm{~h}$ and $72 \mathrm{~h}$ subgroups according to the culture time for permeability study $(n=5)$, and 3, 6, 12, 24, 48 h for membrane constituents study $(n=5)$, and $12 \mathrm{~h}$ sample for morphology study. Each experiment was repeated five times. Membrane permeability was determined by flow cytometry, membrane morphology of BRL was observed by electronic microscope, and constituents were determined by automatic biochemistry analysator and thin layer chromatography scanning method.

Vinegar-baked bupleuriradix increased the BRL membrane permeability significantly, and this effect was vinegar-baked bupleuriradix concentration dependent, at all the time points, high concentration vinegar-baked bupleuriradix had a stronger effect than that of low concentration, and as the culture time prolonged, the effect of vinegar-baked bupleuriradix concentration on the permeability was more obvious. Further study showed that the membrane permeability increase was not due to membrane breakage, but prompting the growth of BRL cell. Morphology study showed that compared with the control group, the cell surface was much smoother after co-cultured with medium and high dose of vinegarbaked bupleuriradix, the effect was drug dose dependent. In order to study the reason, the content of cholesterol, protein and lipids were determined. Vinegar-baked bupleuriradix had marginal effect on the content of cholesterol, and the effect of vinegar-baked bupleuriradix on the lipids and protein content was dependent on the culture time and drug dose. 
Cholesterol/phospholipids reflected cell integrity and permeability, when it decreased, the increase of permeability is toxic to cells, in this study, however, compared to the control group, high and medium dose of vinegar-baked bupleuriradix increased the ratio at 3, 12, 24 $\mathrm{h}$, only decreased the ratio at $6 \mathrm{~h}$, low dose of vinegar-baked bupleuriradix had marginal effect on the ratio.

Proportion among lipids is related with membrane fluidity, and it is related with membrane permeability, especially phosphatidylcholine/phosphatidyl ethanolamine ratio. Like cholesterol/phospholipids ratio, when it is decreased, cells are under danger. However, vinegar-baked bupleuriradix increased the ratio before $12 \mathrm{~h}$, and thereafter, it had marginal effect on it. Membrane constituents were related with transporters, and the effect of vinegarbaked bupleuriradix on the activity of P-glycoprotein in BRL cell line was also studied, and the results showed that vinegar-baked bupleuriradix inhibited the activity of Pglycoprotein, this is in accordance with the results of morphological and membrane constituents results, and indicated that liver targeting effect of vinegar-baked bupleuriradix may be related with transporters.

\subsection{Study of lung meridian guide drug: platycodiradix}

Platycodiradix is the root of Platycodon grandiflorum A. DC, and it is widely used in treating diseases of lung and respiratory system, such as laryngopharyngitis, bronchitis, asthma, pulmonary tuberculosis, and pneumonia in clinics in China. Pharmacological research showed that it is responsible for diverse effects including anti-inflammation, anti-allergy, anti-tumor, augmentation of immune response, anti-obesity, anti-oxidation, hypoglycemic activity etc (Y.Tai et al, 2009). It is described in book <Ben Cao Qiu Zhen> that platycodiradix could promote the function of lung, and guide other drugs to lung. Therefore, it is the meridian guide drug of lung.

The lung target enhancing effect of platycodiradix was studied by pharmacokinetics method. Animals were divided into two groups, drug alone group and drugs coadministration with platycodiradix. Drug concentration and the target evaluation were listed in Table 3. The studied components included levofloxadin (Y.L, Li et al., 2006), florenicol (Y.L. Li et al., 2008), and roxithromycin (Y.L. Li et al., 2005).

\begin{tabular}{|l|l|l|l|l|l|}
\hline component & animal & Detection method & $\begin{array}{l}\text { Detected } \\
\text { components }\end{array}$ & Drug dose & $\begin{array}{l}\text { Target } \\
\text { evaluation }\end{array}$ \\
\hline levofloxacin & chicken & HPLC & levofloxacin & $10 \mathrm{mg} / \mathrm{kg}$ & Cmax, AUC \\
\hline Florfenicol & rabbit & HPLC & florfenicol & $30 \mathrm{mg} / \mathrm{kg}$ & Cmax, AUC \\
\hline roxithromycin & chicken & $\begin{array}{l}\text { Biological effect } \\
\text { method }\end{array}$ & roxithromycin & $8,10,12 \mathrm{mg} / \mathrm{kg}$ Cmax, AUC \\
\hline
\end{tabular}

Table 3. Experiment design of lung targeting effect of platycodiradix

Platycodiradix increased the distribution of levofloxacin, florfenicol in lung significantly and this effect is platycodiradix dose dependent and components property related. The most sensitive component was levofloxacin. When co-administered with platycodiradix, Cmax of levofloxacin in lung increased 4.4 times; and its AUC increased 470\%, although platycodiradix also increased the AUC of levofloxacin in heart and kidney, the increased extent was far less than that in lung. Florfenicol was less sensitive than levofloxacin. Platycodiradix increased Cmax and AUC of florfenicol in lung. However, it also increased 
the distribution of florfenicol in liver. Meanwhile it decreased Cmax of florfenicol in blood and kidney with the decreased extent of $28 \%$ and $44 \%$ respectively.

\begin{tabular}{|l|l|l|l|l|l|l|}
\hline Drugs & $\begin{array}{l}\text { AUC } \\
\text { Changed } \\
\text { extent in } \\
\text { lung }\end{array}$ & $\begin{array}{l}\text { Cmax } \\
\text { Changed } \\
\text { extent } \\
\text { inlung }\end{array}$ & $\begin{array}{l}\text { AUC Changed } \\
\text { extent in other } \\
\text { tissues }\end{array}$ & $\begin{array}{l}\text { Cmax Changed } \\
\text { extent in other } \\
\text { tissues }\end{array}$ & $\begin{array}{l}\text { Drug } \\
\text { distribution } \\
\text { original }\end{array}$ & $\begin{array}{l}\text { Distribution } \\
\text { ratio of drug } \\
\text { in lung }\end{array}$ \\
\hline levofloxacin & $440 \%$ & $470 \%$ & $\begin{array}{l}-15 \% \text { in liver, } 50 \% \\
\text { in kidney, } 44 \% \text { in } \\
\text { heart }\end{array}$ & $\begin{array}{l}-14 \% \text { in liver, } \\
72.7 \% \text { in heart, } \\
103 \% \text { in kidney }\end{array}$ & $\begin{array}{l}\text { Kidney>=liver } \\
>\text { heart=lung }\end{array}$ & $8.5 \%$ \\
\hline Florfenicol & $50 \%$ & $59.7 \%$ & $\begin{array}{l}-26 \% \text { in blood, } \\
76.8 \% \text { in liver }\end{array}$ & $\begin{array}{l}-28 \% \text { in blood, } \\
44 \% \text { in kidney } \\
110 \% \text { in liver, }\end{array}$ & $\begin{array}{l}\text { Kidney> } \\
\text { lung liver> }> \\
\text { heart }\end{array}$ & $10.4 \%$ \\
\hline $\begin{array}{l}\text { Roxithro- } \\
\text { mycin }\end{array}$ & $\begin{array}{l}\text { No } \\
\text { significance }\end{array}$ & $36 \%$ & - & - & - & - \\
\hline
\end{tabular}

Table 4. Results of lung targeting effect of Platycodiradix, _ represent no data

Effect of platycodiradix on the distribution of roxithromycin was a little different from that of others. Although at $10 \mathrm{mg} / \mathrm{kg}$ dose, platycodiradix increased Cmax of roxithromycin, it had marginal effect on AUC, platycodiradix enhanced drug absorption, Tmax of roxithromycin was 3 or $4 \mathrm{~h}$ for medium and low dose respectively, when co-administered with platycodiradix, Tmax was $0.75 \mathrm{~h}$ and $1.5 \mathrm{~h}$ respectively. In control group, drug was absorbed slowly, and there were 3 peaks, but in experimental group, there was only 1 peak. Multi-peak usually indicated liver-intestine cycle, and platycodiradix may be able to inhibit this cycle and induce a rapid elimination. Since effect of platycodiradix on drug distribution in other tissues was not studied, effect of platycodiradix on roxithromycin is not complete. This limited our knowledge.

\subsection{Effect of borneol on brain targeting}

Borneol, a simple bicyclic monoterpene with acrid-bitter flavor, belongs to heart, spleen and lung meridian, it has the effect of communicating holes and scattering stagnant fire, detumescencing and relieving the pain. It is frequently used in the treatment of encephalopathy, such as stroke, epilepsy and headache. Pharmacological study showed that borneol had the effect of anti-excitation of central nerve induced by picrotoxin, prolong the delitescence of hyperspasmia, prolong the survival time of mice under oxygen deficiency, and prolong the awareness of tired rats (S.R.Wu \& G.Cheng et al, 2001).

In the book "Amplification on Canon of Materia Medical", it is said that "borneol is weak when used alone, it strengthens the therapeutic action of other herbs when it is used as an adjuvant and message drug", it also had the effect of "commanding other drugs". In <Plain Questions of Huangdi's Internal Classic>, it is said that "Heart, King of organs, mind efferens", "heart controls mental and emotional activities", that is to say, brain function in ancient China was listed as "Heart". Therefore it is the meridian guide drug of brain.

\subsubsection{Borneol increased drug concentration in brain}

Brain targeting effect of borneol was studied by determining drug concentration in brain and pharmacological method. Drugs studied using the first method included sodium ferulate (Z.Z. Lin et al, 2008), carbamazepine (H.Y. Zhou et al, 2008), tetramethylpyra (Y. 
Wang et al, 2006), methotrexat (Gao et al, 2009), rifampici (S.R. Wu et al, 2004), Panax pseudo-ginsing (S.X. Wang et al, 2009), puerarin (C.Y. Gao et al, 2010), gastrodin (Cai et al, 2008), cidomycin (Q.D. Liu et al, 1994), danshensu (J. Liu et al, 2008) et al. The study design was listed in Table 5.

\begin{tabular}{|c|c|c|c|c|c|c|}
\hline Drugs & Animal & $\begin{array}{l}\text { Detection } \\
\text { method }\end{array}$ & $\begin{array}{l}\text { Detected } \\
\text { components }\end{array}$ & $\begin{array}{l}\text { Drug } \\
\text { dose } \\
\mathrm{g} / \mathrm{kg}\end{array}$ & $\begin{array}{l}\text { Meridian } \\
\text { guide drug } \\
\text { dose }(\mathrm{g} / \mathrm{kg})\end{array}$ & Target evaluation \\
\hline Sodium ferulate & mice & HPLC-MS & Sodium ferulate & 0.2 & $0.05,0.002$ & $\begin{array}{l}\text { Concentration in brain } \\
\text { and blood }\end{array}$ \\
\hline Carbamazepine & mice & HPLC & $\begin{array}{l}\text { Carbamazepine, } \\
\text { 10,11- epoxide } \\
\text { carbamazepine }\end{array}$ & & 0.75 & Cmax, AUC \\
\hline $\begin{array}{l}\text { Tetramethyl- } \\
\text { pyrazine }\end{array}$ & rat & HPLC & $\begin{array}{l}\text { Tetramethyl- } \\
\text { pyrazine }\end{array}$ & 0.0034 & 0.034 & $\begin{array}{l}\text { Concentration in blood } \\
\text { and brain }\end{array}$ \\
\hline methotrexat & Rabbit & HPLC & Methotrexat & 0.1 & 0.75 & Concentration in brain \\
\hline Cidomycin & rat & $\begin{array}{l}\text { Enzyme } \\
\text { immu- } \\
\text { nization }\end{array}$ & cidomycin & 0.035 & 1.0 & Concentration in brain \\
\hline rifampici & Mice & HPLC & rifampici & 0.182 & 0.6 & AUC \\
\hline \begin{tabular}{|l} 
notoginsenoside \\
R1
\end{tabular} & rabbit & HPLC & notoginseng R1 & 15.0 & 0.085 & $\begin{array}{l}\text { Concentration in } \\
\text { tissues }\end{array}$ \\
\hline $\begin{array}{l}\text { Ginsenoside } \\
\text { Rg1 }\end{array}$ & rabbit & HPLC & ginsenoside Rgl & 15.0 & 0.085 & Concentrationin tisues \\
\hline $\begin{array}{l}\text { Ginsenoside } \\
\operatorname{Re} \\
\end{array}$ & rabbit & HPLC & ginsenoside $\operatorname{Re}$ & 15.0 & 0.085 & $\begin{array}{l}\text { Concentration in } \\
\text { tissues }\end{array}$ \\
\hline Puerarin & Rats & HPLC & puerarin & 0.0625 & 0.3 & AUC in brain \\
\hline gastrodin & mice & HPLC & gastrodin & 0.2 & $0.4,0.6$ & $\begin{array}{l}\text { AUC in brain and } \\
\text { blood }\end{array}$ \\
\hline danshensu & rabbit & HPLC-MS & Danshnsu & 10 & 0.18 & $\begin{array}{l}\text { Concentration in } \\
\text { tissues }\end{array}$ \\
\hline
\end{tabular}

Table 5. Experiment design of brain targeting effect of borneol

Among these drugs, cidomycin is aminoglycoside antibiotic, puerarin is a kind of flavonoid, notoginsenoside R1, ginsenoside Rg1 and Re are saponin, rifampici is rifomycins antibiotics, methotrexat is antifolate drug. Borneol increased their distribution in brain, and this effect is borneol dose dependnt and chemical structure related. In the study of borneol to the distribution of gastrodin, 40 and $60 \mathrm{mg} / \mathrm{kg}$ borneol increased the distribution of gastrodin in brain significantly. However, $20 \mathrm{mg} / \mathrm{kg}$ had marginal effect on the distribution of gastrodin. Among the reported study, Ginsenoside Rg1 was the most sensitive compound to the effect of borneol, and drug concentration increase in brain was $2438 \%$. Although it also increased drug concentration in other tissues, the increased ratio was far less than that in brain. The second sensitive component was notoginsenoside R1, the increased ratio of drug concentration in brain was $523 \%$, and borneol also increased drug concentration in other tissues in the meantime. The originally distribution of these two components in brain was 
very low. Borneol also had the effect of decreasing drug concentration in non-target tissues. For example, borneol decreased the concentration of tetramethylpyrazine in blood, and decreased the concentration of rifampici in liver and kidney.

\begin{tabular}{|c|c|c|c|c|c|}
\hline Drugs & $\begin{array}{l}\text { \% Change } \\
\text { of AUC in } \\
\text { Brain }\end{array}$ & $\begin{array}{l}\% \text { Change } \\
\text { of Con- } \\
\text { centration } \\
\text { in brain }\end{array}$ & $\begin{array}{l}\text { AUC Change in } \\
\text { other tissues }\end{array}$ & $\begin{array}{l}\text { Cmax Change in } \\
\text { other tissues }\end{array}$ & $\begin{array}{l}\text { Drug distribution } \\
\text { original }\end{array}$ \\
\hline Sodium ferulate & $66 \%$ & \begin{tabular}{|l|l|}
$47 \%$ \\
\end{tabular} & No significance & $46 \%$ in blood & - \\
\hline Carbamazepine & $24.5 \%$ & $129 \%$ & $\begin{array}{l}-9 \% \sim-37 \% \text { in } \\
\text { lung, liver, } \\
\text { heart and } \\
\text { kidney }\end{array}$ & $\begin{array}{l}14 \% \sim 29 \%, \text { in liver, } \\
\text { lung, blood, heart, } \\
\text { muscle, } 175 \% \text { in } \\
\text { spleen }\end{array}$ & $\begin{array}{l}\text { Lung }>\text { brain }>\text { fat }> \\
\text { liver }>\text { blood }> \\
\text { kidney }>\text { spleen } \\
>\text { heart }>\text { muscle }\end{array}$ \\
\hline $\begin{array}{l}\text { epoxide } \\
\text { carbamazepine }\end{array}$ & $174.5 \%$ & $56 \%$ & $\begin{array}{l}-52 \sim-40 \% \text { in } \\
\text { lung, liver and } \\
\text { heart }\end{array}$ & \begin{tabular}{|l|}
$146 \%$ in spleen, - \\
$38 \%,-20.5 \%,-53 \%$ in \\
lung, liver and \\
heart respectively
\end{tabular} & $\begin{array}{l}\text { Lung }>\text { heart }>\text { liver }> \\
\text { kidney }>\text { blood }> \\
\text { brain }>\text { fat }>\text { spleen }> \\
\text { muscle }\end{array}$ \\
\hline $\begin{array}{l}\text { Tetramethylpyr } \\
\text { azine }\end{array}$ & $30 \%$ & $26 \%$ & $-15 \%$ in blood & $-10 \%$ & - \\
\hline methotrexat & $75 \%$ & $56.5 \%$ & No significance & No significance & - \\
\hline Cidomycin & - & $142 \%$ & - & 22.8 & _ \\
\hline rifampici & $99 \%$ & $79 \%$ & $\begin{array}{l}-12 \%,-17 \%, \\
64 \%, 46 \% \text { in } \\
\text { liver, kidney } \\
\text { lung and blood } \\
\text { respectively }\end{array}$ & $\begin{array}{l}-40 \%,-24 \% 75 \% \text { in } \\
\text { liver , kidney and } \\
\text { lung respectively }\end{array}$ & $\begin{array}{l}\text { Liver }>\text { kidney }> \\
\text { lung }>\text { blood }>\text { brain }\end{array}$ \\
\hline $\begin{array}{l}\text { notoginsenoside } \\
\text { R1 }\end{array}$ & - & $523 \%$ & -- & $\begin{array}{l}497 \%, 227 \%, 36 \% \\
20 \% \text { in liver, lung, } \\
\text { heart, kidney }\end{array}$ & $\begin{array}{l}\text { Heart }>\text { kidney }> \\
\text { lung }>\text { liver }>\text { brain }\end{array}$ \\
\hline ginsenoside Rgl & - & $2438 \%$ & - & $\begin{array}{l}927 \%, 567 \% \text { and } \\
491 \% \text { in heart, } \\
\text { kidney, liver }\end{array}$ & $\begin{array}{l}\text { lung> liver > kidney } \\
>\text { heart > brain }\end{array}$ \\
\hline ginsenoside Re & - & $71 \%$ & - & $\begin{array}{l}264 \%, 251 \%, 85 \% \\
73 \% \text { in, liver, lung, } \\
\text { heart, kidney }\end{array}$ & $\begin{array}{l}\text { Kidney }>\text { heart }> \\
\text { brain= liver }>\text { lung }\end{array}$ \\
\hline Puerarin & $191 \%$ & - & - & - & \begin{tabular}{|l|} 
Lung $>>$ kidney $>$ \\
pancreas $>$ liver $>$ \\
heart $>$ spleen $>$ brain \\
\end{tabular} \\
\hline gastrodin & $109 \%$ & $80 \%$ & No significance & No significance & \\
\hline Danshensu & - & $355 \%$ & & $\begin{array}{l}-100 \%, 158 \%, \\
104 \% \text { in heart, liver, } \\
\text { kidney respectively }\end{array}$ & $\begin{array}{l}\text { Kidney> heart> } \\
\text { brain >liver }\end{array}$ \\
\hline
\end{tabular}

Table 6. Effect of borneol on drug distribution of other drugs

Among these studies, only in the study of carbamazepine, the effect of borneol on the metabolite of carbamazepine was studied. Borneol also increased the distribution of the metabolite of carbamazepine in brain, and decreased its distribuion in lung, liver and heart, 
also showed a brain targeting effect. However, since most of these studies only pay attention to the blood-brain barrier, effect of borneol on drug distribution in other tissues was neglected, and this limited our knowedge of borneol on the absorption, distribution, elimination and excretion of the studied drugs.

\subsubsection{Brain action enhancing effect of borneol}

Besides pharmacokinetics study, pharmacological method was also used to demonstrate the effect of borneol. Ischemic reperfusion usually induces brain injury. Although some drugs are effective for ischemic reperfusion, low drug concentration in brain limited their effect. Sodium ferulate is one of these drugs.

Chen Xiao-Hong et al studied the brain curative enhancing effect of borneol on sodium ferulate by ischaemia reperfused model (X. H. Chen et al, 2010). Mice were randomly divided into 6 groups $(n=6)$ : sham-treated, which was administered $10 \%$ ethanol, treated group included sodium ferulate $100 \mathrm{mg} / \mathrm{kg}$ per day, sodium ferulate $400 \mathrm{mg} / \mathrm{kg}$ per day, borneol $10 \mathrm{mg} / \mathrm{kg}$ per day, sodium ferulate $100 \mathrm{mg} / \mathrm{kg}+10 \mathrm{mg} / \mathrm{kg}$ borneol per day, sodium ferulate $400 \mathrm{mg} / \mathrm{kg}+10 \mathrm{mg} / \mathrm{kg}$ borneol per day. Therapy was initiated $30 \mathrm{~min}$ before or after ischaemia reperfused. To evaluate the treatment effects, tissues of the mice were collected for brain oedema analysis after $24 \mathrm{~h}$ of ischaemia reperfusion, for BBB permeability detection after $48 \mathrm{~h}$ and for Morris water maze test after 4 days of ischaemia reperfusion. Ischemic reperfusion model was made by the bilateral common carotid artery occlusion method. The results showed that compared with sham-operated group, the ischaemia reperfused mice were associated with long-lasting spatial learning deficits in the absence of other behavioral impairments and with neurodegeneration in the hippocampal CA1 region. However, the histological injuries were significantly attenuated by oral co-administration of sodium ferulate with borneol. Furthermore, combined treatment with sodium ferulate and borneol resulted in a significant reduction in brain oedema, gliofibrillar acid protein-positive cells, and blood-brain barrier permeability, but an increase in superoxide dismutase activity, indicating a brain targeting enhancing effect.

Artherosclerosis is the patho-basis for coronary disease and stroke. Dioscin, a component from plants of dioscoreaceae, lilium and pulse family, is usually used to treat coronary disease but due to blood- brain barrier, it is seldomly used to treat stroke. Wang Guang-Jian et al investigated the cure effect of dioscin on stroke when co- administered with borneol ( G.J. Wang, 2010).

Rats were divided into five groups randomly, that is control group (sham operation group), model group, dioscin group $(0.2 \mathrm{~g} / \mathrm{kg})$, dioscin $(0.2 \mathrm{~g} / \mathrm{kg})$ co-administered with borneol $(0.01 \mathrm{~g} / \mathrm{kg})$ and dioscin $(0.2 \mathrm{~g} / \mathrm{kg})$ co-administered with borneol $(0.02 \mathrm{~g} / \mathrm{kg})$. Animals were administered drugs or equal volume of isotonic $\mathrm{Na}$ chloride (for control and model group). After 7 days, besides control group, animals in other groups were made into cerebral ischemia model by block arteria cerebri media. After the animals were recovered, their neurology was given a mark. Thereafter, animals were sacrificed, brain were taken out, dyeing and calculated the ratio of cerebral infarction.

The results showed that no neurologic impairment was found in control group. Animals in model group appeared ptosis, enophothamos, the neurology mark increased significantly, and cerebral infarction ratio was $12.9 \%$. Compared with model group, cerebral infraction ratio and neurology mark of animals in dioscin and dioscin co-administration with low dose of borneol group had a tendency of decreasing, however, dioscin co-administered with high 
dose of borneol decreased the cerebral infarction ratio and neurology mark significantly, indicating a very obvious synergy effect.

\subsubsection{Mechanism study of borneol}

The most accepted thought is that low drug concentration in brain is due to blood- brain barrier. And mechanism studies about borneol were focused on the blood- brain barrier and its tight junction. Zhao Bao-Sheng and Liu Qi-De studied the effect of borneol on bloodbrain barrier, and compared its effect with the blood-brain opening under pathological condition (B.S.Zhao \& Q.D. Liu, 2002). The activity of anti-induce nitric oxide synthetase antibody (iNOS) in capillary endotheliocyte of brain was determined by streptomycinbioepiderm - oxidase linking method. Compared with normal control group, iNOS in normal animals administered with borneol did not increase, while in animals with brain injured iNOS increased significantly, indicating that the opening of blood-brain barrier induced by borneol was different from that under pathological conditions. Ultrastructure of the blood-brain barrier influenced by borneol were also studied (Ge et al, 2008). It was showed that compared with the control group, borneol loosened the tight junction and some of the tight junction was not continuous. After $24 \mathrm{~h}$, the ultrastructure turned to normal, also indicating a reversible effect.

Since many factors are not easily controlled in vivo, people studied the effect of borneol on tight junction of BBB using different cell models. Chen Yan-Ming \& Wang Ning-Sheng et al studied effect of borneol on the BBB model constructed by MDCK cell line (Y.M. Chen and N.S. Wang, 2004). First, borneol was administrated to rabbits for 4 consective days, and blood were taken out, the concentration of borneol in serum determined by GC-MS was $133 \mu \mathrm{g} / \mathrm{mL}$. Study was carried out by comparing the BBB among MDCK cells co-cultured with serum at different time and concentration, containing or not containing borneol. After $4 \mathrm{~h}$ co-culture with serum containing $0.086 \mu \mathrm{mol} / \mathrm{L}$ borneol, the tight junction was open, after $24 \mathrm{~h}$ co-culture with serum containing borneol at the same concentration, the number and volume of pinocytosis vesicles in the BBB cells increased significantly, thus accelerating the transport of substances by cell pinocytosis. However, $24 \mathrm{~h}$ after removing serum contained borneol, effect of borneol disappeared and there was no difference in morphology when compared with normal cell. This is in accordance with the in vivo effect, also indicating a reversible effect.

P-glycoprotein is multidrug resistant protein. There are lots of P-glycoprotein in BBB, and some people think it is one of the reasons that BBB restrains other drugs from getting into the brain. Chen Yan-Ming \& Wang Ning-Sheng studied the effect of borneol on the vinblastine toxicity in MDCK and Hela cell line, verapamil was the positive control. It was found that borneol increased the toxicity of vinblatine in both cell lines significantly, and the increased degree was similar to that of verapamil, indicating that borneol may be able to inhibit the activity of P-glycoprotein (Y.M Chen. \& N.S.Wang, 2003).

Histamine and 5- hydroxytryptamine take part in the regulation of BBB, therefore, Li WeiRong et al studied the effect of borneol on the content of histamine and 5hydroxytryptamine. The results showed that borneol increased the contents of histamine and 5-hydroxytryptamine in brain significantly, indicating that effect of borneol on BBB may be related with histamine and 5-hydroxytryptamine (W.R. Li et al, 2006).

\subsection{Meridian guide effect of achyranthisradix}

Achyranthisradix is the radix of Achyranthes bidentata BI. It tastes sweet, a little bitter and sour, belongs to kidney, liver meridian. It had the effect of enforcing the function of liver 
and kidney, strengthening bones and muscle, inducing float fire to descend and promoting diuresis for stranguria. In clinic, it is usually used to treat gonarthritis, swelling of throat caused by flaring up of stomach fire, and gingivitis etc. A famous physician Wang Ang in Qing dynasty said in his book <Essentials of Metea Medica> that "achyranthisradix induces fire to descend". Zhang Xi-Chun said in his book <Yi Xue Zhong Zhong Can Xi Lu> that "achyranthisradix induces fire and blood to descend". In book <Han Wen Tiao Bian>, it is described that "achyranthisradix, when used without baking, its property descends quickly, it could cure emia and amenia, induce other drugs to descend". In book <Ben Cao Feng Yuan>, it was reported that "achyranthisradix induces other drugs to the lower part, arthrolithiasis of bones and muscles at the lower part should use it". It is the meridian guide of lower limb.

Pharmacological study revealed that achyranthisradix enhanced lympholeukocyte to reproduce, and increased the secretion of IL-2, decreased the Sil-2 content in old rats. It also increased the SOD activity, LPO content in old and feeble rats. Besides, it had the effect of anti-tumor, anti- inflammatory, anti- bacteria, and analgesic (Meng \& Li, 2001). Its meridian guide effect was studied by pharmacokinetics combined with pharmacological method.

Rats were divided into five groups randomly, that is normal control group, model control group, achyranthisradix group $(5 \mathrm{~g} / \mathrm{kg})$, diclofenac sodium $(10 \mathrm{mg} / \mathrm{kg})$ group, achyranthisradix $(5 \mathrm{~g} / \mathrm{kg})$ co-administered with diclofenac sodium group $(10 \mathrm{mg} / \mathrm{kg}$ for diclofenac sodium). Besides normal group, Freud's compete adjuvant $(0.1 \mathrm{~mL})$ were injected at right voix pedis of rats in other groups, and made the inflammatory model for 28 days by measuring weights and the volume of voix pedis each week. At the 22 day, drugs were administered to rats and the drug administration continued to the 28 day. On the last day, after measuring weight and volume of voix pedis, rats were anesthetized, and blood was collected from hepatic portal vein. Afterwards rats were sacrificed, right voix pedis was cut down and the skin was removed, the soft tissues were weighed and homogenized, the content of diclofenac sodium in blood, and voix pedis was determined by high performance liquid chromatography, the content of PGE2 was determined by kit., the content of IL-1 $\beta$ was determined by radio-immunity kit.

Compared with normal control group, right voix pedis in model group swelled significantly $(\mathrm{P}<0.01)$, both PGE and IL-1 $\beta$ increased significantly. In the study of diclofenac sodium, compared to the model group, both diclofenac sodium and its co-administration with achyranthisradix inhibited the swell significantly, achyranthisradix alone had marginal effect on the swell. Compared with diclofenac sodium, effect of inhibited swell was more effective in the group co-administered with achyranthisradix, showing a synergistic effect. Diclofenac sodium decreased both the PGE content in blood and inflammatory tissues significantly, and there was no difference between the decreased ratio in blood and inflammatory tissues. Achyranthisradix had marginal effect on PGE content, however when co-administered with diclofenac sodium, it decreased PGE content both in blood and inflammatory tissues significantly, and the decreased ratio in inflammtory tissues was more obvious, and this is different from the effect of diclofenac sodium. Same results was obtained when comparing the content of IL- $1 \beta$. Both diclofenac sodium alone and coadministration with achyranthisradix decreased the content of IL-1 $\beta$ significantly, the latter had no significance when compared with normal control group, all these results showed that achyranthisradix could enhance the effect of diclofenac sodium. Besides, compared with model group, diclofenac sodium decreased the weight of rats significantly, when co- 
administered with achyranthisradix, the weight of rats increased, indicating that achyranthisradix decreased the side effect of diclofenac sodium (Y.Q Lin, 2009).

Drug concentration in tissues gave a clue for the pharmacological results. When coadministered with achyranthisradix, concentration of diclofenac sodium in blood decreased, and drug concentration in inflammatory site increased significantly, the decreased and increased extent were $75 \%$ and $10 \%$ respectively.

\section{Meridian guide drug and transporters}

Above results showed that meridian guide drug enhanced the curative effect of the coadministered drugs and this effect was induced by the increased distribution of other drugs in target site or decreased distribution in non-target site. This is in accordance with modern theory, and demonstrated that meridian guide drug could be used as a target delivery method. Drug concentration in tissues is a balance of uptake and elimination. Uptake could be reflected by Cmax. Almost all the results in pharmacokinetics studies showed that meridian guide drug increased a Cmax of other drugs in target site, this indicated that increasing the uptake is one of the ways for the effect of meridian guide drug. Elimination rate could be calculated by the concentration- time profile. Meridian guide drug usually increased the elimination in non- target site in above studies. Usually, drug uptake into cells and efflux to outside through two methods, one is passive diffusion, the other is active transport. Passive diffusion mainly depends on the property of the drugs, and fewer factors could affect it. Active transport is different, since it needs the help of carriers, factors which affected the activity directly or indirectly would affect its transport efficiency. Above results indicated that the effect of meridian guide drug may be related with influx and efflux transporters.

Mechanism study also gives some clues for meridian guide drug with transporters. In cell surface, there are lots of lipid raft related with the transport of xenobiotics and endogenous metabolites. Vinegar-baked bupleuriradix increased the permeability of BRL cell line, and in high dose the cell surface changed smoothly, indicating a change at transport capability. Further study indicated that this change was due to membrane constituents change.

Transporters is a kinds of protein resides in membrane and is responsible for the across of xenobiotics and endogenous metabolites into cells. Transporters could be divided into two families according to their transport directions, and they are influx transporters and efflux transporters. Influx transporters include organic anion transport protein (OAT), organic anion transport polypeptide (OATP), organic cation transport protein (OCT) and organic cation transport polypeptide (OCTP). Efflux transporters, also named as ATP- binding cassette $(\mathrm{ABC})$ transporter super-family, include $\mathrm{P}$ - glycoprotein (P-gp), the multi-drug resistance protein family (MRP1-9), the breast cancer resistance protein (BCRP). There are many excellent reviews about them (H. Miyazaki et al, 2004; Kusuhara \& Sugiyama, 2002; Shirata et al, 2006; M. L. Elaine et al, 2005; S. Gergely, 2008). The distribution of transporters is vary with different tissue, and the results are listed in Table 8. For example, OAT1 was expressed in kidney, brain, uterus, but OCT 1 was predominantly expressed in liver, and had trace amount in kidney; OAT3 was expressed in kidney, liver, brain, and eye; MRP1 was extensively expressed in most organs, and had a high expression in lung, testicle, kidney, musculi skeleti, peripheral blood mononuclear cell etc, but had a relatively low expression in liver (B. Hagenbuch \& C. Gui, 2008; M. Huls et al, 2009; M. Elaine, 2005; C. J. Endres, 2006). More and more studies showed that transporters play a major role in drug absorption, distribution, toxicity, efficacy, elimination and excretion. And it is a main reason 
for drug-drug interaction. Some drugs affected the activity of transporters and as a consequence affected the distribution of the substrate of transporters (S. Eberl et al, 2007; A.Y. Coban et al, 2004 ; A. Seithel, et al, 2007, Sikri et al, 2004 ). Most of the meridian guide drugs had the effect of inhibiting the activity of P-gp (Q. Wu, 2005), and many drugs studied above such as resveratrol (A.Lancon et al, 2004, Juan et al, 2010), rhein (Garbap, 2002), levofloxacin (T. Ito et al, 1997), danshensu (P.F.Yu et al, 2011) are the substrate of P-gp or Mrp, indicating that meridian guide drug may influence the activity of these transporters and affect drug distribution and its pharmacological action.

By analyzing the pharmacokinetics data, this hypothesis could be further elucidated. Cmax is a parameter reflecting drug absorption. The increase in Cmax suggested an uptake increase and efflux decrease in intestine. Levofloxacin is the substrate of OATP (T. Maeda et al, 2007), P-gp (T. Ito et al, 1997) and MRPs (H. Polache et al, 2010), which are located in intestine, platycodiradix inhibited the activity of P-gp and Mrps and may also increase the activity of OATP, the Cmax of levofloxacin increased $470 \%$. Resveratrol is the substrate of MRP2 (M. E. Juan et al, 2010; Lancan A, 2004), which transported drug from the liver to blood and induced a significantly increased blood concentration. Drug distribution and elimination is the balance of drug affinity to different tissues. As shown in Table 8, different tissues had different transporters or different content of the same transporters, and the affinity with different transporters was determined by the influx and efflux rate of the drug and as a sequel, the balance in different tissues determined distribution, elimination, and excretion of the drug.

\begin{tabular}{|l|l|l|l|l|}
\hline Transporters & Gene & $\begin{array}{l}\text { Transporter } \\
\text { distribution }\end{array}$ & Substrates & Inhibitors \\
\hline P-gp & ABCB1 & $\begin{array}{l}\text { brain, intestine, } \\
\text { liver, kidney, } \\
\text { placenta, lung, } \\
\text { stomach, colon, } \\
\text { pancreatic gland, } \\
\text { oesophagus }\end{array}$ & $\begin{array}{l}\text { danshensu, } \\
\text { roxithromycin, } \\
\text { quinolone, } \\
\text { levofloxacin, } \\
\text { berberine, rifampicin } \\
\text { ofloxacin }\end{array}$ & $\begin{array}{l}\text { Bupleuri Radix, cimicifugate, } \\
\text { cortex moutan, coptis } \\
\text { chinensis, cortex } \\
\text { phellodendri, anemarrhenae, } \\
\text { Tetramethylpyrazine, } \\
\text { platycodiradix, borneol, } \\
\text { berberine, matrine, } \\
\text { saikosaponin, paeoniflorin, } \\
\text { baicalin, Roxithromycin, } \\
\text { puerarin }\end{array}$ \\
\hline Mrp1 & $A B C C 1$ & $\begin{array}{l}\text { Testicle, skeletal } \\
\text { muscle, heart, } \\
\text { kidney, lung, } \\
\text { Brain, intestine, } \\
\text { liver (trace) }\end{array}$ & $\begin{array}{l}\text { rhein, methotrexate } \\
\text { puerarin } \\
\text { kidney, brain, } \\
\text { placenta }\end{array}$ & $\begin{array}{l}\text { Methotrexate } \\
\text { resveratrol } \\
\text { diclofenac } \\
\text { baicalein }\end{array}$ \\
\hline Mrp2 & $A B C C 2$ & $\begin{array}{l}\text { Tetramethylpyrazine, } \\
\text { puerarin }\end{array}$ \\
\hline Mrp3 & ABCC3 & $\begin{array}{l}\text { Adrenal gland, } \\
\text { Intestine, } \\
\text { Pancreas, } \\
\text { Gallbladder }\end{array}$ & $\begin{array}{l}\text { Methotrexate } \\
\text { Placenta, Liver, }\end{array}$ & $\begin{array}{l}\text { Tetramethylpyrazine, } \\
\text { puerarin, }\end{array}$ \\
\hline Mrp4 & $A B C C 4$ & Methotrexate & \\
\hline
\end{tabular}




\begin{tabular}{|c|c|c|c|c|}
\hline Transporters & Gene & $\begin{array}{l}\text { Transporter } \\
\text { distribution }\end{array}$ & Substrates & Inhibitors \\
\hline & & $\begin{array}{l}\text { Kidney, Prostate } \\
\text { Ovary, Testis, } \\
\text { Kidney, Lung, } \\
\text { Prostate }\end{array}$ & & \\
\hline MRP5 & ABCC5 & $\begin{array}{l}\text { Liver, Testis, } \\
\text { Skeletal and } \\
\text { Cardiac Muscle, } \\
\text { Brain }\end{array}$ & & Tetramethylpyrazine \\
\hline MRP6 & ABCC6 & $\begin{array}{l}\text { Kidney, } \\
\text { keratinocytes, } \\
\text { liver tracheal, } \\
\text { bronchial, } \\
\text { epithelium, } \\
\text { intestinal } \\
\text { mucosa, corneal } \\
\text { epithelium, } \\
\text { smooth muscle } \\
\text { cell }\end{array}$ & & \\
\hline BCRP & ABCG2 & $\begin{array}{l}\text { Placenta, colon, } \\
\text { intestine, liver, } \\
\text { heart, brain, } \\
\text { kidney, prostate, } \\
\text { ovary }\end{array}$ & $\begin{array}{l}\text { Methotrexate, } \\
\text { resveratrol } \\
\text { Ofloxacin }\end{array}$ & \\
\hline OAT1 & SLC22A6 & $\begin{array}{l}\text { Kidney, brain, } \\
\text { eye, placenta }\end{array}$ & & $\begin{array}{l}\text { Cidomycin, diclofenac, } \\
\text { Methotrexate }\end{array}$ \\
\hline OAT2 & SLC22A7 & Liver, kidney & & Methotrexate \\
\hline OAT3 & SLC22A8 & $\begin{array}{l}\text { Liver, intestine, } \\
\text { liver, Blood } \\
\text { cerebrospinal } \\
\text { fluid barrier, } \\
\text { placenta } \\
\end{array}$ & & Methotrexate \\
\hline OAT4 & SLC22A11 & $\begin{array}{l}\text { Liver, placenta, } \\
\text { kidney, adrenals }\end{array}$ & & Methotrexate \\
\hline OAT5 & SLC22A & Liver, kidney & & Methotrexate \\
\hline OAT10 & SLC22A13 & $\begin{array}{l}\text { Kidney, brain, } \\
\text { heart, colon }\end{array}$ & & \\
\hline OCT1 & SLC22A1 & $\begin{array}{l}\text { Liver, intestine, } \\
\text { lung, heart, } \\
\text { placenta }\end{array}$ & & \\
\hline OCT2 & SLC22A2 & $\begin{array}{l}\text { Liver, kidney, } \\
\text { brain, intestine }\end{array}$ & & \\
\hline OCT3 & SLC22A3 & $\begin{array}{l}\text { Liver, intestine, } \\
\text { placenta, } \\
\text { brain,heart }\end{array}$ & & \\
\hline OCTN1 & SLC22A4 & $\begin{array}{l}\text { Kidney, liver, } \\
\text { testis, muscle, } \\
\text { heart }\end{array}$ & & \\
\hline
\end{tabular}




\begin{tabular}{|c|c|c|c|c|}
\hline Transporters & Gene & $\begin{array}{l}\text { Transporter } \\
\text { distribution }\end{array}$ & Substrates & Inhibitors \\
\hline OCTN2 & SIC22A5 & $\begin{array}{l}\text { Kidney, liver, } \\
\text { brain, intestine, } \\
\text { testis }\end{array}$ & & \\
\hline OATP1A2 & SLCO1A2 & $\begin{array}{l}\text { Brain, liver, } \\
\text { kidney, eye }\end{array}$ & \begin{tabular}{|l|} 
Levofloxacin \\
Methotraexate \\
\end{tabular} & rifampicin \\
\hline OATP2B1 & SLCO2B1 & $\begin{array}{l}\text { Brain, liver, } \\
\text { kidney, placenta, } \\
\text { intestine }\end{array}$ & levofloxacin & Roxithromycin, rifampicin \\
\hline OATP1B1-3 & SLCO1B & Liver & $\begin{array}{l}\text { Rifampicin, } \\
\text { methotrexate }\end{array}$ & $\begin{array}{l}\text { Rifampicin } \\
\text { cimicifugae }\end{array}$ \\
\hline OATP3A1 & SLCO & ubiquitous & $\begin{array}{l}\text { Rifampicin, } \\
\text { methotraexate }\end{array}$ & Rifampicin \\
\hline OATP4A1 & SLC & ubiquitous & & Rifampicin \\
\hline OATP1C1 & SLC & $\begin{array}{l}\text { Brain, testis, } \\
\text { heart, lung, eye }\end{array}$ & & Rifampicin \\
\hline OATP1AB3 & SLC & Liver & & Rifampicin \\
\hline PEPT1 & SLC & $\begin{array}{l}\text { Liver, kidney, } \\
\text { intestine }\end{array}$ & & \\
\hline PEPT2 & SLC & $\begin{array}{l}\text { Kidney, brain, } \\
\text { lung, spleen, } \\
\text { lacteal gland }\end{array}$ & & \\
\hline
\end{tabular}

Table 8. Distribution, substrate, and inhibitors of transporters.

The activity and expression of transporters could be affected by many factors, such as xenobiotics, diseases, stress, metabolism enzyme, microenvironment change. And as a sequence, meridian guide drug may affect drug distribution by affecting these factors directly or indirectly. Efflux transporters are usually ATP dependent, drugs affecting ATP enzyme would affect activity of transporters and then affect drug effectiveness and toxicity (MunićV. et al, 2010; Regev et al, 1999). Bupleuriradix inhibited the activity of Na-K ATP enzyme (Q.L. Zhou et al, 1996), and may indirectly affected the activity of transporters.

Different transporters may be affected by different factors, and a factor may have different effect on different transporters. MRP is affected by many factors, and even in this family, despite of a great homology in family members, factors had different effect on different MRPs. Drugs may affect transporters by affecting the factor and thereafter affected other drugs distribution. For example, MRP1 is a glutathione dependent transporter, but other transporters of MRP family are glutathione independent. Water extract of bupleuriradix increased the glutathione content (M.H. Yen et al, 2005), and enhanced the activity of MRP1. MRP1 is expressed widely in other tissues but less in liver, leading to a fast elimination rate in other tissues, while it had marginal effect on drug elimination in liver. This may be one of the reasons for its toxicity reducing effect.

In spite of above well known transporters there are some transporters such as Mate1-2, RLIP76, and aquaporin, may play a role in meridian guide effect (Tanihara 2007, Ohta et al, 2009; Singhal, 2009). For example, carbamazepine is an active drug for epilepsy, and it has drug-resistant phenomenon. P-gp was first considered as the reason, however, study showed it is not the substrate of P-gp (Maines, 2005). Further studies showed that it is also not the substrate of MRP (Luna-Tortós et al, 2010; F. Rivers, 2008), BCRP (L. Cerveny et al, 
2006). Recently, Awasthi et al found that RLIP76, a multifunctional modular protein, was involved in its drug-resistance (S. Awasthi et al, 2005). Borneol increased the brain concentration of carbamazepine, probably by inhibiting the activity of RLIP76.

Besides transporters, drug metabolism enzyme had an important effect on drug absorption, distribution, elimination and excretion. Most of meridian guide drug affected the activity of metabolism enzyme, such as pueraria, cassia bark, incised notopterygium rhizome, coptis chinensis, cortex phellodendri, evodiaefructus, angelica root, forsythia suspensa, paeoniaeradix and bupleuriradix, angelica dahurica etc. And this also may be one of reasons for its meridian guide effect (Yang et al, 2002; Mao et al, 2007, X.L. Bi et al, 2010). However, there are many herbs which could affect drug transporters and metabolism enzyme and they are not the meridian guide drug. For example, ginseng is drug usually used to invigorate vital energy, the main components of it not only affected drug metabolism but inhibited P-gp as well (C.H. Choi et al, 2003; S.W. Kim et al, 2003; S. Kitagwa Et al, 2007; Y.R. Pokharel, 2010); many herbs contained flavone, such as sophoraeflos, Chinese hawthom, soybean which also could affect drug metabolism enzyme and transporters (R.X. Zhu et al, 2011; Y.H. Liu et al, 2011) and only few of them are meridian guide drug, therefore, there must be other factors co-operating this effect and further study is required.

\section{Conclusion}

In summary, meridian guide drug had the effect of synery and attenuation, and this effect is based on drug concentration at target-site. Meridian guide effect had a close relationship with drug transporters and metabolism enzymes. Different components had different affinity to transporters or enzymes, and meridian guide effect is a combination of all components in meridian guide drug. Therefore, it is necessary to investigate the exact effect of main components of meridian guide drug on transporters and metabolism enzymes, establish the relationship between its dose and its effect as well as effects on different kinds of diseases. As we know more about the relationship among components in meridian guide drug, kinds of transporters and metabolism enzymes, activity in nomal and disease state, we could design target delivery system freely as desired.

\section{Acknowledgements}

This research was financially supported by the found of National Science Foundation of China (Grant No. 30672668, 81073063)

\section{References}

Awasthi S., Hallene K. L, Fazio V., Singhal S. S , Cucullo L., Awasthi Y. C, Dini G. and Janigro D. (2005). RLIP76, a non-ABC Transporter, and Drug Resistance in Epilepsy, BMC Neuroscience, VOL. 6, No. 61, doi:10.1186/1471-2202-6-61

Bi X.L., Du Q, Di L.Q., (2010). Important Application of Intestinal Transporters and Metabolism Enzymes on Gastrointestinal Disposal of Active Ingredients of Chinese Materia Medica, Zhongguo Zhongyao Zazhi, Vol.35, No.3, (February, 2010), ISSN 1001-5302

Cerveny L., Pavek P., Malakova J., Staud F., and Fendrich Z., (2006). Lack of Interactions between Breast Cancer Resistance Protein (BCRP/ABCG2) and Selected Antiepileptic Agents, Epilepsia, Vol.47, No.3, pp.461-468, ISSN 0013-9580 
Chen S.M., Sato N., Yoshida M., Satoh N., Ueda S. (2008). Effects of Bupleurum scorzoneraefolium, Bupleurum falcatum, and Saponins on Nephrotoxic Serum Nephritis in Mice. Journal of Ethnopharmacology, No 116 , (November, 2008) ,pp. 397402, ISSN 0378-8741

Chen X. H., Lin Z.Z., Liu A.M, Ye J.T., Luo Y.Y, Mao X.X., Liu P.Q. and Pi R.B., (2010). The Orally Combined Neuroprotective Effects of Sodium Ferulate and Borneol Against Transient Global Ischaemia in C57 BL/6 Mice, Journal of Pharmacy and Pharmacology, No.62, (July, 2010), 915-923, ISSN 0022-3573

Chen Y.M., Wang N.S., (2004). Effect of Borneol on the Intercellular Tight Junction and Pinocytosis Vesicles in vitro Blood Brain Barrier, Zhongguo Zhongxiyi Jiehe Zazhi, Vol.24, No. 7,(July, 2004), pp.632-634, ISSN 1003-5370

Chen Y.M., Wang N.S., (2003). Effect of Borneol on P-gp, Zhongyao Xinyao Yu Linchuang Yaoli, Vol.14, No.2, (April, 2003), pp.96-99, ISSN 1003-9783

Chiang L.C., Ng L.T., Liu L.T., Shieh D., Li C.C., (2003). Cyctoxicity and Anti-Hepatitis B Virus Activities of Saikusaponins from Bupleurum, Planta Med, No.69, pp. 705-709, ISSN 0032-0943

Coban A. Y., Ekinci B., Durupinar B., (2004). A Multidrug Efflux Pump Inhibitor Reduces Fluoroquinolone Resistance in Pseudomonas aeruginosa isolates, Chemtherapy, No.50, pp.22-26. ISSN 0009-3157

Eberl S., Renner B., Neubert A., Reisig M., Bachmakov I., König J., Dörje F., Thomas E. M, Ackermann A., Dormann H., Gassmann K.G., Hahn E. G., Zierhut S., Brune K. and Fromm M. F. (2007). Role of P-Glycoprotein Inhibition for Drug Interactions Evidence from In Vitro and Pharmacoepidemiological Studies, Clin Pharmacokinet, Vol.46, No,12, pp.1039-1049, ISSN 0312-5963

Elaine M. Leslie, Roger G. Deeley, Susan P.C. Cole, (2005). Multidrug Resistance Proteins: Role of P-glycoprotein, MRP1, MRP2, and BCRP (ABCG2) in Tissue Defense, Toxicology and Applied Pharmacology, No.204, pp.216- 237, ISSN 0041-008X

Endres C. J., Hsiao P., Chung F. S., Unadkat J.D., (2006). The Role of Transporters in Drug Interactions, European journal of pharmaceutical sciences, No. 27, pp. 501-517, ISSN 0928-0987

Fu W. K., (1990). History of Chinese medicine (1st), ShangHai Zhongyi Xueyuan Publishing Company, Shanghai, China. ISBN 7-81010-093-9

Gao C., Gao M., Shi W.Z., Zhao Z.G, Sun H., Zhao X.L., (2009). Experimental Study on the Effect of Borneol for Methotrexate Penetrating Across Blood Brain Barrier, Zhongguo Linchang Yaolixue Zazhi Vol.25, No.2, (April, 2009), pp. 134-137, ISSN 1001-6821

Gao C.Y, Li X.R., Li Y.H., Wang L.J. and Xue M., (2010). Pharmacokinetic Interaction Between Puerarin and Edaravone, and Effect of Borneol on the Brain Distribution Kinetics of Puerarin in Rats. Journal of pharmacy and pharmacology,No.62, (March, 2010), pp.360-367, ISSN 0022-3573

Ge C.L, Han M.F, Bai R.T., Yu C.,(2008). Effect of Borneol Oil the Ultrastructure of Promoting Blood Brain Barriar Open, Zhongxiyi Jiehe XinNao Xueguanbing Zazhi, Vol.6, No. 10, (October, 2008), pp. 1183-1185, ISSN 1672-1349

Gergely S., Andras V., Csilla O.L., and Balazs S. (2008). The Role of ABC Transporters in Drug Absorption, Distribution, Metabolism, Excretion and Toxicity (ADMETox), Drug Discovery Today, Vol.13, No. 9/10, pp.379-393, ISSN 1359-6446

Gorkom BAP van, Timmer-Bosscha H., Jong S de, Kolk DM van der, Kleibeuker JH and Vries EGE de (2002). Cytotoxicity of Rhein, the Active Metabolite of Sennoside 
Laxatives, is Reduced by Multidrug Resistance-associated Protein 1, British Journal of Cancer, No. 86, pp.1494 - 1500, ISSN 0007-0920

Hagenbuch B. \& Gui C., (2008). Xenobiotic Transporters of the Human Organic Anion Transporting Polypeptides (OATP) Family, Xenobiotica, Vol.38, No.7-8, (JulyAugust, 2008), pp.778-801, ISSN 0049-8254

Huls M., Russel F. G. M., and Masereeuw R., (2009). The Role of ATP Binding Cassette Transporters in Tissue Defense and Organ Regeneration, The Journal of Pharmacology and Experimental Therapeutics, Vol. 328, No.1, (January, 2009), pp. 3-9, ISSN 00223565

Ito T, Yano I, Tanaka K., and Inui, (1997), Transport of Quinolone Antibacterial Drugs by Human P-glycoprotein Expressed in Kidney Epithelial Cell Line, LLC-PK, The journal of Pharmacology and Expermental Therapeutics, No. 282 pp. 955-960, ISSN 00223565

Juan M. E., Gonzalezález-Pons E., and Planas J. M., (2010). Multidrug Resistance Proteins Restrain the Intestinal Absorption of trans-Resveratrol in Rats, The Journal of Nutrition; Vol.140, No.3, (March, 2010), pp.489-495, ISSN 0022-3166

Kim S.W., Kwon H.Y., Chi D.W., et al, (2003). Reversal of P-glycoprotein- Mediated Multidrug Resistance by Ginsenoside Rg3, Biochem Pharmacol, No.65, pp.75-82, ISSN, 0006-2952

Kitagwa S., Takahshi T., Nabekura T., Tagchikawe, and Hasegawa H, (2007). Inhibitory Effects of Ginsenosides and Their Hydrolyzed Metabolites on Daunorubicin Transport in KB-C2 Cells, Biol. Pharm. Bull., Vol.30. No. 10, pp.1979-1981, ISSN 1347-5215

Kou W-M., 2006. Effect of Radix Bupleuri Processing Method on the Drug Action and its Rule in Clinical Use, Shizhen Guoyi Guoyao, Vol.17, No. 10 (October, 2006), pp. 19981999, ISSN 1008-0805

Kusuhara H., Sugiyama Y., (2002). Role of Transporters in the Tissue-Selective Distribution and Elimination of Drugs: Transporters in the Liver, Small Intestine, Brain and Kidney, Journal of Controlled Release No.78, pp.43-54, ISSN 0168-3659

Lancon A., Delmas D., Osman H., J.-P. , Thenot, and Jannin B., Latruffe N., (2004). Human Hepatic Cell Uptake of Resveratrol: Involvement of Both Passive Diffusion and Carrier-mediated Process, Biochemical and Biophysical Research Communications No.316, (February, 2004), pp. 1132-1137, ISSN 0006-291X

Lin Y.Q.,Sun B., Yang S.Y., Lv L., Liu Y., (2009). Therapeutic Effect of Radix Achyranthis Bidentatae Guiding Function on Diclofenac Sodium Induced Adjuvant Rats Arthritis, Zhongyao Xinyao Yu Linchuang Yaoli, Vol.20, No.5, (October, 2009), pp. 408-411, ISSN 1003-9783

Lin Z.Z, Yao M.C., Lan M. X., Liu P.Q., Zhong G.P., Pi R. B., (2008). Effects of Borneol on Distribution of Sodium Ferulate in Plasma and in Brain Regions of Mice, Zhong Cao Yao, Vol.39, No.4, (April, 2008), pp.551-556, ISSN 0253-2670

Liu J., Li X., Hu S.S., Yu Q.L, Sun W.J., Zheng X.H., (2008). Studies on the Effects of Baras Camphor on the Tissue Distribution of Salvia miltiorrhiza Bge. in Complex Danshen Prescription in Rabbits, Yaowu Fenxi Zazhi, Vol.28, No.10, (October, 2008), pp.16121615, ISSN 0254-1793

Liu Q.D., Liang M.R, Chen Z.X., (1994). The Influence of Borneol on the Passing of Gentamycin through Blood-Brain Barrier, Guangzhou Zhongyiyao Daxue Xuebao Vol.11, No.1, (January, 1994), pp.87-90, ISSN 1007-3213 
Liu Y.H., Mo S.L., Bi H.C., Hu B.F., Li C.G., Wang Y.T., Huang L., Huang M., Duan W., Liu J.P., Wei M.Q., Zhou S.F., (2011). Regulation of Human Pregnane X Receptor and its Target Gene Cytochrome P450 3A4 by Chinese Herbal Compounds and a Molecular Docking Study, Xenobiotica. Vol.41, No.4, (April, 2011), pp.259-80, ISSN 0049-8254

Li W.R., Yao L.M., Mi S.Q., Wang N.S., (2006). Relation of Openness of Blood-Brain Barrier by Borneol with Histamine and 5-Hydroxytryptamine, Zhongguo Linchuang Kangfu, Vol.10, No.3, pp.167-169, ISSN 1671-5926

Li X.D., (2000). Comparative Analysis of Active Composition of Radix Bupleuri Before and After Being Processed, Zhong YI Yao Xue Bao, Vol. 22, No.7 (July, 2000), pp.483-484, ISSN 1002-2392

Li Y. L., Cui H.M., Chen H. W., (2008). Effect of Platycodon Grandiflorum on Pharmacokinetics of Florfenico, Zhongguo ShouYi Xuebao, Vol. 28, No.10 (October, 2008), pp. 1203-1207, ISSN 1005-4545

Li Y. L, Jiang Z. G., He X. L. (2006). Effect of Chinese Herb Platycodon Grandiflorum Leading Action on Distribution of Levofloxacin in Chickens After Oral Administration, Zhongguo ShouYi Xuebao Vol.26, No.5, (May, 2006), pp.541-543, ISSN 1005-4545

Li Y. L., Lu S. M., Jian M., (2005). Effect of Chinese Herb Platycodon Grandiflorum on Roxithromycin Concentration of Lung Tissue, Zhongguo ShouYi Xuebao, No. 3, (March, 2005), pp.3-6 ISSN 1005-4545

Luna-Tortós C., Fedrowitz M. , Löscher W., (2010). Evaluation of Transport of Common Antiepileptic Drugs by Human Multidrug Resistance-Associated Proteins (MRP1, 2 and 5) that Are Overexpressed in Pharmacoresistant Epilepsy, Neuropharmacology, No. 58, (January, 2010), pp 1019-1032, ISSN 0028-3908

Maeda T., Takahashi K., Ohtsu N., Oguma T., Ohnishi T. Atsumi R., and Tamai I., (2006). Identification of Influx Transporter for the Quinolone Antibacterial Agent Levofloxacin, Molecular Pharmaceutics, Vol. 4, No. 1, (October, 2007), pp.85-94, ISSN 1543-8384

Maines L. W., Antonetti D. A., Wolpert E. B., Smith C.D., (2005). Evaluation of the Role of PGlycoprotein in the Uptake of Paroxetine,Clozapine, Phenytoin and Carbamazapine by Bovine Retinal Endothelial Cells, Neuropharmacology No.49, pp. 610-617, ISSN 0028-3908

Mao X.Q, Xie H.T., Zhou H.H, (2007). MDR- and CYP3A4- Mediated Drug-herb Interactions, Zhongguo Linchuang Yaolixue Yu Zhiliaoxue, Vol 12, No 7 (July, 2007), pp 728-734, ISSN 1009-2501

Meng D.L. \& Li X., (2001). The Research Development of Achyranthesbidentata B1, Zhongguo Yaowu Huaxue Zazhi, Vol. 40, No.2, (February, 2001): 120-124, ISSN 10050108

Miyazaki H., Sekine T. and Endou H., (2004). The Multispecific Organic Anion Transporter Family: Properties and Pharmacological Significance, TRENDS in Pharmacological Sciences, Vol.25, No. 12, pp. 654-662, ISSN 0165-6147

Nie S., Liu X.P., Chen Sh.W, Li K., (2008). Study on Fingerprint of Bupleurum Chinese and Vinegar-baked Bupleurum Chinese in Hubei Province, Zhong Yao Cai, Vol .31, No.5, (May, 2008), pp. 657-659, ISSN 1001-4454

Nie S.Q, Yang Q., Li L.F, Huang L.Q, (2002). Pharmacokinetics Comparisons of Bupleurum Root and Red Peony Root, Vinegar-baked Bulpeurum Root and White Reony Root 
between Compatibility and Single Application, Zhongguo Shiyan Fangii Xue Zazh, Vol.8, No.3, (March, 2002), pp. 11-14, ISSN 1005-9903

Ohta K.Y., Imamura Y., Okudaira N., Atsumi R., Inoue K., and Yuasa H., (2009). Functional Characterization of Multidrug and Toxin Extrusion Protein 1 as a Facilitative Transporter for Fluoroquinolones, The Journal of Pharmacology and Experimental Therapeutics, Vol. 328, pp.628-634, ISSN 0022-3565

Pokharel Y.R., Kim ND, Han HK, Oh WK, Kang KW, (2010). Increased Ubiquitination of Multidrug Resistance 1 by Ginsenoside Rd. Nutr Cancer. Vol.62, No.2, pp.252-9, ISSN 1531-7914

Choi C.H., Kang G., Min Y.D, (2003). Reversal of P-glycoprotein-mediated Multidrug Resistance by Protopanaxatriol Ginsenosides from Korean Red Ginseng.Planta Med., Vol.69, No. 3 (Mar,2003), pp.235-40, ISSN 0032-0943

Regev R., Assaraf Y. G. and Eytan G. D., (1999). Membrane Fluidization by Ether, Other Anesthetics, and Certain Agents Abolishes P-glycoprotein ATPase Activity and Modulates Efflux from Multidrug-resistant cells, Eur. J. Biochem. 259, 18-24, ISSN 0014-2956

Rivers F., ÓBrien T. J., Callaghan R., (2008). Exploring the Possible Interaction between antiEpilepsy Drugs and Multidrug Efflux Pumps; in vitro Observations, European Journal of Pharmacology No.598, (September, 2008),pp 1-8, ISSN 0014-2999

Seithel A., Eberl S., Singer K., Auge D., Heinkele G., Wolf N. B., Dorje F., Fromm M.F., and Konig J., (2007). The Influence of Macrolide Antibiotics on the Uptake of Organic Anions and Drugs Mediated by OATP1B1 and OATP1B3, Drug Metabolism and Disposition, No.35, (May, 2007) pp.779-786, ISSN 0090-9556

Shitara Y., Horie T., Sugiyama Y., (2006). Transporters as a Determinant of Drug Clearance and Tissue Distribution, European Journal of Pharmaceutical Sciences, No.27, pp. 425446, ISSN 0928-0987

Sikri V., Pal D., Jain R., Kalyani D., and Mitra A. K., (2004). Cotransport of Macrolide and Fluoroquinolones, a Beneficial Interaction Reversing P-glycoprotein Efflux, American Journal of Therapeutics No. 11, pp.433-442, ISSN 1075-2765

Singhal S.S., Yadav S., Roth C., Singhal J., (2009). RLIP76: A Novel Glutathione-conjugate and Multi-drug Transporter Biochemical Pharmacology, No. 77, pp. 761- 769, ISSN 0006-2952

Tai Y., Hou J. P., Meng J.G., Xu W.W., Wang Q., (2009). Pharmacological Development of Platycodiradix, Xiandai Zhongyiyao, No.6, (June, 2009), pp. 74-75, ISSN 1672-0571

Tanihara Y., Masuda S., Sato T., Katsura T., Ogawa O., Inui Ken-ichi, (2007). Substrate Specificity of MATE1 and MATE2-K, Human Multidrug and Toxin Extrusions/H+Organic Cation Antiporters, Biochemical Pharmacology, No.74, pp.359- 371, ISSN 0006-2952

Wang B.J., Liu C.T., Tseng C.Y, Wu C.P., Yu Z.R., (2004). Hepatoprotective and Antioxidant Effects of Bupleurum Kaoi Liu (Chao et Chuang) Extract and Its Fractions Fractionated Using Supercritical CO2 on CCl4-induced Liver Damage, Food and Chemical Toxicology, No. 42, (November, 2004) , pp. 609-617, ISSN 0278-2915

Wang G. J., Zhang B., Zhang X. S., Zhang E. H., (2010). Effect of Dioscin Co-administration with Borneol on Cerebral Ischemia Induced by MCAO, Zhongyao Yaoli Yu Linchuang Vol. 26, No. 5, (October, 2010), pp. 54-55, ISSN 1001-859X

Wang S. X., Miao W. L., Fang M. F., Nan Y. F., Meng X., Yu J., Zheng X. H., (2009). Effect of Borneol on the Tissue Distribution of Notoginseng R1, Ginsenoside Rgl and Re in 
Rabbits, DiSi Junyi Daxue Xuebao, Vol. 30, No.23, (December, 2009), pp. 2750-2752, ISSN 1000-2790

Wang Y., Zhang Z.Y., Xu F., Wang B.J., Zhang S.Y., (2006). Effects of Borneol on Concentration of Tetramethylpyrazine in Blood and Distribution in Brain of Rat, Zhongguo Yaoye, Vol.15, No.1, (January, 2006), pp.30-31, ISSN 1006-4693

Wu J., (2008). Effect of Process on Components and Pharmacological of Radix Bupleurum, Hubei Zhongyi Zazhi Vol. 30, No. 9, (September, 2008), pp.60-61, ISSN 1000-0704

Wu S. R., Cheng G., He Y.X., Hao X. H., Wang L., Sun J., (2004). Studies on the Effects of Borneol on the Distribution of Rifampicin in Mice, Zhongguo Yaoxue Zazhi, Vol. 39, No.4 (April, 2004), pp. 289-291, ISSN 1001-2494.

Wu Q., (2005). Effect of Meridian Guide Drug on P-gp, Xiandai Yufang Yixue, Vol.32, No.7, (July, 2005), pp.855-856, ISSN 1003-8507

Wu S.R., Cheng G.,(2001). Pharmacological Development of Borneol, Zhong Cao Yao, Vol.32, No.12, (December, 2001), pp.1143-1145, ISSN 0253-2670

Yang X. F., Wang N. P., Zeng F. D., (2002) Effect of the Active Components of Some Chinese Herbs on Drug Metabolizing- Enzymes, Zhongguo Zhongyao Zazhi, Vol. 27, No. 5 (May, 2002), pp. 325-328, ISSN 1001-5302

Yu P.F., WangW. Y., Eerdun G., WangT., Zhang L.M., Li C., and Fu F.H,2011. The Role of PGlycoprotein in Transport of Danshensu across the Blood-Brain Barrier, EvidenceBased Complementary and Alternative Medicine Vol. 2011, Article ID 713523, 5 pages doi:10.1155/2011/713523

Zhao B.S., Liu Q. D, (2002). Difference Between Borneol and Pathological on Blood-Brain Barrier, Zhongyao Xinyao Yu Linchuang Yaoli, Vol.13, No. 5, (October, 2002), pp. 287-288, ISSN 1003-9783

Zhao R.Z., Liu S.J, (2005). TCM Tradicinal Guide Theory and Target-tropism Administration, Zhong Yi Za Zhi, volume 46, No. 9, (September, 2005), pp. 643-645, ISSN 1001-1668

Zhao R.Z., Liu S.J., Mao S. R., Wang Y.J., (2009). Study on Liver Targeting Effect of Vinegarbaked Radix Bupleuri on Resveratrol in Mice, Journal of Ethnopharmacology, No.126, (September, 2009), pp.415-420, ISSN 0378-8741

Zhao R.Z., Yuan D, Liu S.J., Chen YJ., Liu L.J. Zhao Y. (2010). Liver Targeting Effect of Vinegar-baked Radix Bupleuri on Rhein in Rats, Journal of Ethnopharmacology, No. 132, (October, 2010), pp. 421-428, ISSN 0378-8741

Zheng C., Xiang H. S., Li Y. B., Zhao B. B., Yang Z. X., Xu S.G., Pu J.X., (2008). Effect of Borneol on the Distribution of Gastrodin to the Brain in Mice via Oral Administration, Journal of Drug Targeting, Vol.16, No.2, (February, 2008), pp178184, ISSN 1061-186X

Zhou H. Y., Chen X. Y., Huang C. K., Jiang W. G., Hu G. X.. (2008), Effect of Borneol on Distribution of Carbamazepine in Mice, Wenzhou Yixueyuan Xuebao, Vol.38, No.4, (July, 2008), pp.300-305, ISSN 1000-2138

Zhou Q.L., Zhang Z.Q., Nagasawa T., and Hiai S., (1996). The Structure Activity Relationship of Saikosaponins and Glycyrrhizin Derivatives for Na+, K+ ATPase Inhibiting Action, Yaoxue Xuebao, Vol.31, No.7, (July, 1996), pp 496-501, ISSN 02533707

Zhu R.X., Hu L.W., Li H.Y., Su J.,Cao Z.W., and Zhang W.D.,(2011) Novel Natural Inhibitors of CYP1A2 Identified by in Silico and in Vitro Screening, Int J Mol. Sci. Vol. 12, No.5, (May, 2011), pp.3250-3262, doi: 10.3390/ijms12053250, ISSN 2306-2321 


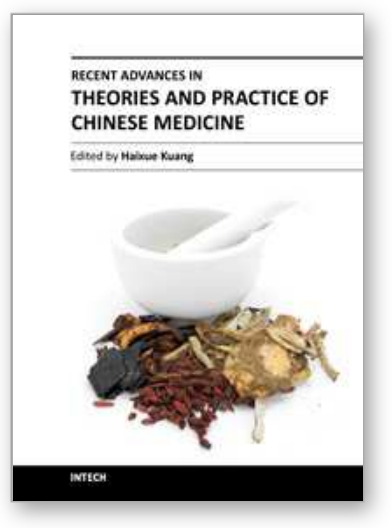

\author{
Recent Advances in Theories and Practice of Chinese Medicine \\ Edited by Prof. Haixue Kuang
}

ISBN 978-953-307-903-5

Hard cover, 504 pages

Publisher InTech

Published online 18, January, 2012

Published in print edition January, 2012

During the recent years, traditional Chinese medicine (TCM) has attracted the attention of researchers all over the world. It is looked upon not only as a bright pearl, but also a treasure house of ancient Chinese culture. Nowadays, TCM has become a subject area with high potential and the possibility for original innovation. This book titled Recent Advances in Theories and Practice of Chinese Medicine provides an authoritative and cutting-edge insight into TCM research, including its basic theories, diagnostic approach, current clinical applications, latest advances, and more. It discusses many often neglected important issues, such as the theory of TCM property, and how to carry out TCM research in the direction of TCM property theory using modern scientific technology. The authors of this book comprise an international group of recognized researchers who possess abundant clinical knowledge and research background due to their years of practicing TCM. Hopefully, this book will help our readers gain a deeper understanding of the unique characteristics of Chinese medicine.

\title{
How to reference
}

In order to correctly reference this scholarly work, feel free to copy and paste the following:

Rui-Zhi Zhao (2012). Targeting Effect of Traditional Chinese Medicine, Recent Advances in Theories and Practice of Chinese Medicine, Prof. Haixue Kuang (Ed.), ISBN: 978-953-307-903-5, InTech, Available from: http://www.intechopen.com/books/recent-advances-in-theories-and-practice-of-chinese-medicine/targetingeffect-of-traditional-chinese-medicine

\section{INTECH}

open science | open minds

\section{InTech Europe}

University Campus STeP Ri

Slavka Krautzeka 83/A

51000 Rijeka, Croatia

Phone: +385 (51) 770447

Fax: +385 (51) 686166

www.intechopen.com

\section{InTech China}

Unit 405, Office Block, Hotel Equatorial Shanghai

No.65, Yan An Road (West), Shanghai, 200040, China

中国上海市延安西路65号上海国际贵都大饭店办公楼 405 单元

Phone: +86-21-62489820

Fax: $+86-21-62489821$ 
(C) 2012 The Author(s). Licensee IntechOpen. This is an open access article distributed under the terms of the Creative Commons Attribution 3.0 License, which permits unrestricted use, distribution, and reproduction in any medium, provided the original work is properly cited. 